\title{
Local Wisdom as Integration of the Cosmic and the Metacosmic Perspectives in Indonesian Philosophy of Education
}

\author{
Antonius Denny Firmanto \\ Sekolah Tinggi Filsafat Teologi Widya Sasana, Indonesia \\ rm_deni@yahoo.com
}

\author{
Nerita Setiyaningtiyas \\ State University of Malang, Indonesia \\ nerita.setiyaningtiyas@gmail.com
}

\begin{abstract}
This study is a literary research on local wisdom of Javanese community as the context. Local wisdom is a proven knowledges owned by the society for sustaining their existence. It influences people's state of mind that relates to human capacity for exploring, discovering and developing human potentiality. This study proposes that in Indonesian context, education as an enhancement process for a better quality of life should make its source on local wisdom. Local wisdom is the "experience" of reality and knowledge is its "expression". The purposes of this research are: (1) describing the experience of reality consists of the cosmic and the metacosmic perspectives; and (2) understanding the existing local wisdoms as a local knowledge has its value for constructing a new theory on the Indonesian Philosophy of Education.
\end{abstract}

Keywords: philosophy of education, local wisdom, cosmic perspective, metacosmic perspective

\section{THE CONTEXT: THE JAVANESE} CULTURE

Javanese culture is considered among the Javanese communities that live in central Java and western side of east Java. The Javanese cultural design is based on "spiritual" value of man, which are holy, noble, and which are not materialistic (Susantina, 2013). It is a Javanese way for creating, enforcing, and processing of its values. It develops ideas that express the valuable things within its society life. It affects how the Javanese thinks, interacts, communicates, or transmit its knowledge to the next generation (Wicaksono, 2016). The Javanese cultural expressions are known in proverbs, artistic heritage, ceremonies, literature, and other existing forms of human expressions.

It is known proverb, such as: saiyeg saiko praya means people should move together hand in hand in order to achieve their goal. Next example is mangan ora mangan kumpul; it means that people should get together in any condition. It is also known ojo dumeh; it indicates that people should be humble because power or wealth is temporary. It is a popular sayings ojo aji mumpung that people should restrain themselves from becoming greedy. All proverbs show that the Javanese has sensitivity for mutual cooperation and social solidarity (Rachmawati, 2012).

The Javanese Batik, that is cloth decorated by a process of repeated dyeing controlled by the application of wax to the fabric, is full of symbolism (Osborne, 2010). Certain designs and favoured combinations of colours are associated with geographical localities. Both of Yogyakarta and Solo in central Java are known for batiks that are dark in colour and restrained in design, characteristics that echo the norms of public behavior associated with their traditional courts. The batik decorated in the traditional design parang rusak or the "broken sword" proposes that people should work hard. The characteristic curved lines of the Parang could also be translated as waves in the sea; it symbolizes the power and greatness of nature. It is believed that the Parang has also supernatural power, such as bringing victory in war, protection and healing of the sick (Marina, 2014).
Art performances, such as: the wayang kulit (shadow puppet shows) illustrate the Javanese perception on their life and world. The stories are not merely an entertainment or just ordinary event that is told about. It tells the existence of human life that is being of goodness and being of evil, the here and the afterlife (Susantina, 2013). As an instrument of instruction, it urges people to determine what is good and what is bad in order that people live together by giving and helping without expecting anything in return because they are all to be related to every other person in the community (Mungmachon, 2012).

There is another cultural expression. From the fact that rice is a main food for all classes in the Javanese community, the rice cultivation arises. Rituals for Dewi Sri, the Javanese goddess (Wikipedia, 2017), are organized along with seedlings preparation, water management, pest control, or grain conservation as a product of human intelligence accompany rice cultivations. Performing rituals give inner tranquility because it is believed by the Javanese that rice cultivation is not only for preserving human life; but, it expresses the humanity. It symbolizes the human life, that is its birth, growth, pregnancy, and giving a new life. Then, the harvest is a moment of celebration for human work and divine grace.

Conscience on ecological matters shows the Javanese responsibility to problems relating to their role as the members of family or society, such as the Bengawan Solo matters. As a river that is situated between Central Java and western side of East Java, it has historical, geographical and economical aspects (Agung, 2015). The river water flow also indicates the state of mind among the Javanese, such as: alon-alon waton kelakon; it means that everything should be done, slowly but surely.

The final example is the literatures on the Javanese house. The Javanese has a belief that that the original nature is the haunted place, so they must reduce that horrible by installing places in the right direction. How to handle it is described in Kawruh Kalang and Kawruh Griya which is a knowledge which tells how to cut down a tree, considering the quality, size guidelines, and placement of buildings, building timing, and completion of construction as an 
ideal place to live (Rachmawati, 2012). It proposes the building construction that can be moved elsewhere that can be done together by a lot of people.

\section{EPISTEMOLOGICAL VALUES OF LOCAL WISDOM}

Local wisdom is a proven knowledges owned by the society for sustaining their existence. It is "the experience" of reality (Pieris, 1988). The fact that there are differences means that it is a different way of "experiencing". And, local wisdom is its "expression". It is also a knowledge that people has given to community and has developed over time, and continues to develop. This development is based on experience that tested over centuries of use. Individuals or communities practice it within institutions, relationships and rituals (Wicaksono, 2016).

Epistemologically, local wisdom is a collection of facts and relates to the entire system of concepts, beliefs and perceptions that people hold about the world around them (Wicaksono, 2016). Local wisdom can be understood as a local idea that is wise, full of wisdom, good-value, which is comprehended by people (Dahliani, 2015). Accordingly, local wisdom represents value system and norm organized, held, understood, and applied by the local society based on their understanding and experience in interacting and interrelating with environment (Agung, 2015). It includes the way people observe and measure their surroundings, how they solve problems and validate new information.

Therefore, formulation of the local wisdom is a process whereby knowledge is generated, stored, applied and transmitted to others. Within this context, it should be affirmed that there our local people have their own knowledge. Information about this knowledge should be explored and explained because it contains ideas proposed by local genius on how people should live in certain context.

\section{LOCAL WISDOM AS THE INTEGRATION OF THE COSMIC AND THE METACOSMIC PERSPECTIVE}

The Javanese with sensitivity in cosmic forces will work in holistic, comprehensive, and integrated millieu. Accordingly, thinking or learning means that people gives the metacosmic attention to the cosmic order. It directs people to assimilate its conditions to the circumstances of the surrounded area (Rachmawati, 2012). Therefore, innovations through science and technology should consider its values for communities. Local wisdom is the positive behavior of man connecting with nature and the surrounding environment.

The mindset within which local wisdom operates is composed of two complementary elements: a cosmic perspective and a metacosmic perspective. The cosmic perspective is the state of mind when people think about the nature. The nature is not seen as something that is outside of man. The perspective represents a basic human attitude toward the mysteries of life. The mysteries relate to cosmic forces that it is heat, fire, earth and its earthquake, rains and its floods.
The natural elements and forces merge into the mysterious world of invisible powers that maintain the cosmic balance. The metacosmic perspective is the state of mind when people think about the reality that is behind the nature. It is the metacosmic order that belongs to the invisible sphere. It may appear in various rites, rituals, and a class of mediators.

The interplay of the cosmic and the metacosmic levels of experience give a new point of departure for social change and technocratic advancement. The existence of a certain spiritual elites - the sages, the wise, the mediators, the elders - becomes the personal embodiments of metacosmic perspective. The metacosmic perspective acknowledges the presence of the belief in the existence of supernatural forces above human reality. Based on the Javanese culture as the context, "being in community" is the Javanese local wisdom. The idea on becoming a member of the community has its value among the Javanese because it has both of the cosmic perspective and the metacosmic perspective.

From the cosmic perspective, "community" forms a kind of social joint that protects people from natural disaster. But, people learn that nature can be a threat, but also provides benefits and tranquility the whole nature of human life depends on. From the metacosmic perspective, "community" is an integrating mechanism for a society that lives in a mutual support and cooperation. Therefore, as a social category, the community unites various aspects of social life and individual experience together in a way which minimizes uncertainty, tension, and conflict - or at least it is supposed to do so (Kistanto, 2016).

Within the context of "being in community", people are highly praised when they did the community service well. Its process is not by accident, but by design that is done in the spirit of mutual assistance (gotong royong). It is highly praised that people have sense of belonging and togetherness toward a harmonious relationship. This makes them "one family" living with unconditional kindness and generosity. When conflicts arise, the elders and various relatives are the ones who decide how to settle matters (Mungmachon, 2012).

Education in a Javanese society is a process of social interaction (Raharjo, 2013). In maintaining harmonious social life, the Javanese thinks that education should generate good people. A man is not a Javanese yet (belum Jawa) if he cannot perform good conduct to elders and his community, such as mastering language (basa Jawa) and practicing etiquette (tata krama). Being the ideal Javanese (menjadi Jawa) is not merely personal matter for achieving better human condition. It is a process for developing social awareness to others that is shown by talking to other with respectful language (unggahungguh).

\section{CONCLUSION}

Man is always seeking for a way to get a sustainable and a peaceful life. It is believed that it should be a harmonious interaction between nature, science-technology, and man. it symbolizes the mystic 
and social unity of those participating in it. Through culture, the Javanese creates a good living environment.

A falsification model as Western model within a rigid method cannot express how the Javanese grasped knowledge. According to the Javanese, what develops community is what useful to propose harmonious relationship. Learning is not only "transfer of knowledge" but also "transfer of values".

\section{REFERENCES}

[1] Agung, S. L. 2015. The Development of Local Wisdom-Based Social Science Learning Model with Bengawan Solo as the Learning Source. American International Journal of Social Science, 4(4), 51-58.

[2] Dahliani, S. I., \& Setijanti, P. 2015. Local Wisdom in Built Environment in Globalization Era. International Journal of Education and Research, 3(6), 157-166.

[3] Kistanto, N. H. 2016. The Javanese Slametan as Practiced as Tradition and Identity. International Journal of Humanities and Social Science, 6(11), 290295.

[4] Marinaelphick. 2017. Parang Batik Motif. Retrieved December 9, 2016, from https://marinaelphick.com/2014/04/17/parang-batikmotif.

[5] Mungmachon, R. 2012. Knowledge and Local Wisdom: Community Treasure. International Journal of Humanities and Social Science, 2(13), 174-181.

[6] Osborne, M. 2010. Southeast Asia. An Introductory History. Allen \& Unwin: Crows Nest, NSW, Australia.

[7] Rachmawati, M., and Mappajaya, M. 2012. Local Wisdom in Java's Architecture (Studied in Nature, Technology and Humanity). Academic Research International, 3(1), 449-455.

[8] Raharjo, T. 2013. The Impact of Global Culture on Javanese Culture in the Craftsmen Society of Earthenware Craft Arts of Pundong, Bantul, Yogyakarta, Indonesia. IOSR Journal Of Humanities and Social Science (IOSR-JHSS), 16(6), 33-42.

[9] Raharjo, T. 2013. The Impact of Global Culture on Javanese Culture in the Craftsmen Society of Earthenware Craft Arts of Pundong, Bantul, Yogyakarta, Indonesia. IOSR Journal Of Humanities And Social Science (IOSR-JHSS), 16(6), 33-42.

[10] Susantina, S., \& Purnomo, E. P. 2013. Myths and Religions in Javanese Cultural Axiology: A Case Study on Javanese Belief in Indonesia. Journal of Asia Pacific Studies, 13(3), 264-280.

[11] Wicaksono, A., and Susanti, Y. 2016. Addressing Local Knowledge and Local Wisdom Through Writing Using Project Based Learning Viewed from Students' Learning Styles in Cross Culture Understanding Class. Proceding ELTLT International Conference, State University of Semarang.

[12] Wikipedia. 2017. Dewi Sri. Retrieved January 9, 2017, from https://en.wikipedia.org/wiki/Dewi_Sri. 